production in characteristic eighteenth century style, with engravings of buildings such as Porchester Castle and "Carresbrook Castle" as well as a plan of Silchester, lists of "Gentlemen's Names", etc. It is interesting to note that exaggerated emphasis is given to relief. Very little appears to be known of Isaac Taylor. He was a native of Ross in Herefordshire. His first-known map is a Plan of Oxfordshire, issued in 1750 and his last a map of the county of Gloucester, which appeared in 1777. He was both an engraver and a surveyor, and on the map of Hampshire there is a note "Estates are surveyed and mapped". His more important maps, in addition to those named, are Wolverhampton, 1750, County of Hereford, 1754, Hereford City, 1757, Dorset, 1765, County of Worcester, 1772.

\section{Revision of Ordnance Plans}

A LEAFLET on the revision of areas of twenty-five inch plans, issued by the Ordnance Survey, notes that revision is far behind the standard formerly uchieved. The hiatus due to the War meant a gap that would not have been easy to bridge even if other difficulties had not supervened. Road and housing development have led to abnormally quick changes within the last twelve years. But most serious of all has been the effect of the call for public economy. Since 1928, revision has, perforce, been limited to those areas in which development and changes have reached a certain standard. This standard is defined as the addition of 200 houses or equivalent area of factory, road or other development in a six-inch quarter sheet. This principle means the abandonment of the revision of any county as a unit, which in former days was done every twenty years. It has much reduced the areas scheduled annually for revision.

\section{Bibliography of Sir James Frazer's Work}

IN January next Sir James Frazer will celebrate his eightieth birthday. In the same year will fall the fiftieth anniversary of the publication of his first work. To meet the desire of his many friends and admirers, who feel that there should be some appropriate mark of the occasion, which would convey to Sir James the esteem in which he is widely held, it has been decided that a number of learned societies, with which Sir James has been connected, should join under the auspices of the Folk-lore Society in the compilation and publication of a complete bibliography of his writings. It is probable that no form of commemoration could be more appropriate than this. It will serve as a perpetual reminder of the wide range of learning that Sir James has covered in his long life of activity in the service of humane letters and science. The editorship of the volume has been entrusted to Mr. Theodore Besterman, 47 Great Ormond Street, London, W.C.1, to whom subscriptions (10s. 6d.) should be sent.

\section{Distribution of British Animals}

THE significance of the distribution of a species or group of species is often best appreciated by mapplotting. To simplify and encourage this method, an octavo map has been prepared showing the counties and vice-counties of Great Britain as delimited for the Watsonian botanical scheme. The areas are numbered so clearly that no confusion can arise, and the key to the numbers is printed alongside the map. Two series have been prepared; one is printed in black, in the other the county outlines, numbers, and list are printed in blue, so that although perfectly legible in ordinary use, they will disappear when photographed for reproduction. The maps may be obtained from Messrs. Oliver and Boyd, Tweedale Court, Edinburgh, at a cost which runs from $£ 13 s$. a hundred to $£ 22 s$. a thousand for the all black, and $£ 111 s$. 6d. a hundred to $£ 3$ a thousand for the black and blue.

\section{Libraries and Gardening}

A Catalogue of books on gardening, poultry and bees has recently been issued by the Leicester Municipal Libraries. Its contents are illuminating, and show that the gardening public is beginning to take an interest in the scientific aspects of their hobby, craft or vocation. Such volumes as Dr. Keen's "Physical Properties of the Soil", Bourcart's "Insecticides, Fungicides and Weed-Killers", Dr. Kenneth Smith's "Text Book of Agrisultural Entomology" and many others of proved scientific worth show that the modern gardener is alive to the need of moving with the times. More than fifty volumes are included in the section on garden planning, and the kitchen gardener and floriculturist are amply supplied with books. The sections on poultry-keeping and bee-keeping are good, but do not give evidence of such scientific and artistic progress as characterises the volumes on gardening.

\section{North American Birds of Prey}

CoNTINUING its series of reproductions of paintings of birds in North America, the National Geographic Magazine for July illustrates and describes the eagles, hawks and vultures. The descriptive text is by Alexander Wetmore, assistant secretary of the Smithsonian Institution; and the coloured pictures, 28 in number, by Major Allan Brooks, if inclined to be a little hard in texture and colour, are the best American drawings we have seen since the death of Louis Agassiz Fuertes. The present article is the fifth of a series very useful and attractive to bird lovers; the first, including humming birds, swifts and goat-suckers, appeared in July, 1932, the second, with ibises, herons and flamingoes in October, 1932, the third, with crows, magpies and jays in January, 1933, the fourth with woodpeckers in April, 1933, and the sixth will be published at an early date.

\section{Copper-Steel Welding}

The issue of the Scientific American for September contains a short illustrated description of a large Detroit welding plant capable of effecting 2,000 welds of steel parts an hour. The parts are either screwed or tightly fitted together and the joint has a thin copper wire or a paste of copper applied to it. A trolley full of articles is sent through a long tube 